\title{
Mulheres ciumentas, homens enfeitiçados: contribuições ticuna para as reflexões sobre gênero e violência ${ }^{1}$
}

L Aline Moreira Magalhấes

Pesquisadora autônoma, Rio de Janeiro, Rio de Janeiro, Brasil

DOI 10.11606/issn.2316-9133.v24i24p465-486

resumo Este artigo percorre dados etnográficos concernentes às conexóes entre práticas e expectativas sexuais, e a modalidade de violência e regulação social da feitiçaria. Neste contexto, um homem obrigar a mulher em ato sexual não constituía injúria coletiva ou motivo para punição. Não obstante, as mulheres poderiam matá-los via enfeitiçamento, caso insatisfeitas com as inabilidades masculinas, sejam sexuais ou vinculadas às atividades cotidianas. A sugestáo de que estavam enfeitiçados era propagada por comentários dedicados a fomentar suspeitas sobre a promiscuidade das mulheres, que denotava a "vontade de se livrar" dos homens com os quais coabitavam. Enfoca-se, neste sentido, as fronteiras entre possibilidades/práticas sexuais e relações políticas, tais como entretecidas entre homens e mulheres Ticuna, que tangenciam, por sua vez, as formas organizativas desta etnia em favor de seus objetivos e sua existência coletiva.

palavras-chave sexualidade; violência; feitiçaria; política; Ticuna.

Jealous women, bewitched men: ticuna contributions to the reflections on gender and violence

abstract This article explores an ethnographic data about the connections between sexual Ticuna practices, as well as the expectations around them, and the mode of violence and social regulation of witchcraft. Among this group, a man compelling a woman to have a sexual relation with him was not a collective grievance, neither a reason for punishment. Nevertheless, women could kill them through bewitchment if unsatisfied with their inaptitude, whether sexually or in terms of everyday primary activities. Hints that they were bewitched were whispered by comments dedicated to fostering suspicions about the promiscuity 
of women, which meant the "willing to get rid" of the men who they cohabited with. Thus, the focus is on the frontiers between sexual possibilities/practices and politics, as woven in ticuna gender relations, as well as its effects on the mobilization of this ethnic group to ensure their goals and their collective existence.

key-words sexuality; violence; witchcraft; politics; Ticuna.

\section{Introdução}

$\mathrm{Na}$ literatura etnológica, assim como nas representaçóes regionais contemporâneas, os Ticuna são por vezes descritos como um povo náo-guerreiro, refratário ao confronto aberto com o risco de baixas. Evitaram sistematicamente, antes da chegada dos europeus, as beiras do Solimóes, ocupados pelos seus inimigos Omagua, os quais aparecem em alguns mitos e lendas Ticuna realizando incursões contra as suas malocas (NIMUENDAJU, 1952, p. 116; OLIVEIRA, 1988, 2000); são acusados, nos acirrados encontros com estes mesmos antigos inimigos, de terem se refugiado - 'covardemente', nas entrelinhas - igarapés adentro durante a colonização, enquanto os Omagua e outras etnias travavam franca resistência bélica contra a ocupação branca; além das frequentes diásporas para fundar comunidades ou novos lugares de habitação, geralmente em virtude de dissidências internas ou quando alguma guerra alcançava onde estavam (ALMEIDA; MAGALHÁES, 2014). ${ }^{2}$

A indisponibilidade para a guerra coletiva, seguindo esta representação que se constrói em contraste a outros grupos, não implica, contudo, uma suposta predisposição generalizadamente "pacifista", tendo em vista a frequência de homicídios por feitiçaria - geralmente entre pessoas consanguínea e/ou residencialmente próximas - ou os esporádicos assassinatos de feiticeiros com violência física - queimados vivos, baleados com armas de fogo, esfaqueados, espancados etc. Conflitos conjugais estáo no epicentro das acusaçôes e mortes por feitiçaria, e parte significativa destas, por sua vez, refere-se a homens atingidos por feitiços forjados por esposas (ãte) sexualmente promíscuas.

A rigor, qualquer infortúnio decorria de enfeitiçamento, doenças, mortes, assim como qualquer tipo de rejeição indicava ser alvo de feitiços. $Y u$ 'u pulverizava o exercício da acusação em um amplo leque de possíveis detratores ou agressores. Todos ocupavam simultaneamente as posiçóes de potenciais causadores de danos e atingidos por eles, de feiticeiros e enfeitiçados. Esse reconhecimento permitia o desenvolvimento do conflito em todos os seus planos e temporalidades. Eram os conflitos em si, muitos e simultâneos, 
que se tornavam objeto de investigação e reflexão coletiva através dos comentários (e dos metacomentários) sobre atos específicos. Danos, dores, visões e demais sintomas corpóreos deveriam ser mantidos apenas nas longas sessóes de cura e reza, nas quais geralmente participavam apenas parentes corresidentes e rezadores. Quanto mais divulgada a debilidade física de alguém, mais sua integridade estava comprometida, pois suscitava especulaçóes do que o doente fez para que alguém lhe causasse o mal.

Circulavam muitas notícias sobre homens adoentados e mortos porque haviam sido enfeitiçados pelas mulheres com as quais coabitavam. Estas afirmaçóes se respaldavam em outras, a de um conhecimento socialmente compartilhado de que essas mulheres se relacionavam com outros homens além daqueles com os quais coabitavam e porventura tinham filhos. Isto consistia, por si só, motivo para desejarem-lhe não só o mal, mas um afastamento derradeiro. Mulheres, por sua vez, também poderiam ser enfeitiçadas tanto pelos homens com os quais se relacionavam, quanto por outras mulheres, rivais de seu casamento (yetai) $^{3}$ caso houvesse ameaça de separação definitiva. Do contrário, suas eventuais queixas sobre "traiçóes" de seus maridos eram classificadas por eles como "ciúmes". Para homens traídos, em contrapartida, um forte antagonismo e abandono estavam já contidos na suspeita fomentada coletivamente sobre o comportamento sexual das mulheres com quem coabitavam. Em suma, mulheres eram tidas por "ciumentas" quando esporadicamente se queixavam sobre a promiscuidade sexual de seus maridos, ao passo que homens considerados traídos estavam necessariamente enfeitiçados, especialmente quando não se afastavam das mulheres que os enfeitiçavam/traíam. ${ }^{4}$

Quando as mulheres negavam sexo aos homens com os quais coabitavam, um homem me disse certa vez, eles passavam a suspeitar e acusá-las de estarem se relacionando com outros homens. Elas se queixavam das formas por meio das quais seus maridos expunham suas exigências de que deveriam satisfazê-los, utilizando "palavras negativas", e à revelia de seus desejos. Incumbindo-se da tarefa de reduzir os conflitos na comunidade onde sempre residiu, ele recomendava aos homens para que não "tratassem a mulher como se fosse metade humano, metade animal, que ele pode dominar, ordenar, dizer o que tem que fazer". Homens Ticuna, segundo este que me falava, "acham que as mulheres são suas fêmeas", que tem obrigação de satisfazê-los. Por seu turno, a gravidez, ele explicava, era deliberadamente forçada pelo homem: "eles engravidam a mulher de propósito, para manter ela dessa forma. É o homem que faz isso". As mulheres traíam e, por conseguinte, enfeitiçavam, por insatisfação com o comportamento dos respectivos cônjuges, quer porque as obrigavam sexualmente, quer 
porque lhes pareciam insuficientes e inábeis, sexualmente ou no que diz respeito às atividades cotidianas de sustento e cuidados domésticos. Tais comportamentos e inabilidades os tornavam menos atraentes, daí a pouca disponibilidade feminina para o sexo.

Ao atribuir parcialmente uma condição animalesca às mulheres, os homens reconheciam nelas fonte de grande perigo, com capacidade para desfazer-se a qualquer momento da tentativa de controle masculina. Controle significava, principalmente, a atençáo exclusiva da mulher ao homem com o qual coabitava. A estratégia para controlá-la, reduzindo suas chances e seu tempo para trair/enfeitiçar foi claramente explicitada: engravidá-la. "Não é a mulher. São eles que engravidam elas de propósito, porque desse modo elas não vão olhar pra mais ninguém, não vão ter tempo de ficar com outros homens". Quanto mais sua atenção estivesse voltada para a casa, para as crianças, menos tempo e energia teriam para trair seus maridos, deixando-os vulneráveis aos diversos sintomas referentes ao $y u^{\prime} u$.

Segundo este ponto de vista masculino, uma mulher é suficientemente suprida por um homem, isto é, um homem deve ser capaz de satisfazer desejos e expectativas de uma (ou mais) mulher (es). A ausência de maiores perigos conjugais repousava na restriçáo do desejo feminino ao homem com o qual coabitava. Caso ela procurasse outros homens, quer por insatisfaçáo com o comportamento de seu marido ou porque não o desejasse, o homem absorvia o peso moral por ser insuficiente à sua esposa e, se fosse o caso, por náo conseguir dela se afastar. Ao procurar outros homens, as mulheres mostravam publicamente sua insatisfação e, por conseguinte, a inabilidade de um determinado homem em satisfazê-las.

Este texto dirige-se às interseçôes que podem ser estabelecidas entre expectativas recíprocas de comportamento sexual entre os gêneros e modalidades de violência. Este problema ancora-se em alguns fragmentos da teoria revolucionária do século XIX - mais sistematicamente Engels (1975), mas também Marx e Bakunin ${ }^{5}$ - para a qual Morgan contribuiu, que entende as relaçóes de parentesco enquanto "embrióes" das formas organizativas e, portanto, também da regulação da violência. Aí, as relaçôes de força estabelecidas entre homens e mulheres, assim como as modalidades de violência em um plano macro, respondem (ou explicitam) uma organização específica de parentesco. Embora tenha consolidado um olhar atento aos atravessamentos entre concepçôes de parentesco/gênero e as dinâmicas de violência em cada sociedade, o obstáculo desta interpretação reside na "suposição de uma coerência a cada termo da oposiçáo, inexistente na dinâmica que constitui as representaçóes e as relaçóes sociais" (DEBERT e GREGORI, 2008, p. 177). ${ }^{6}$ 
Este tema, por sua vez, remete aos tipos de organizações e ações políticas que emergem do sistema político Ticuna, ou de um sistema político regional consideravelmente influenciado por uma forma Ticuna de exercer política. Ao recuperar alguns aspectos contextuais, pretendo deixar explícita a interpretaçáo teórica aqui adotada a este respeito. Em seguida exploro, a partir de um caso específico, as relaçóes de gênero e as possibilidades e práticas sexuais tais como as narrativas dos meus interlocutores enfatizavam.

\section{Território, cotidiano e política}

Os Ticuna habitam o Alto rio Solimões, região oriental da Amazônia, falam um idioma considerado como um tipo isolado único (SOARES, 1992), compóem uma população de aproximadamente setenta mil pessoas cujo território foi ocupado por três Estados nacionais: Brasil, Peru e Colômbia. ${ }^{7}$ Sucessivos conflitos armados e guerras, a alocação de seringais e suas empresas pelo Estado brasileiro, e a atuação de missionários e movimentos milenaristas que construíram igrejas e atraíram seguidores ao seu entorno, conformaram a atual divisáo dos Ticuna em espaços distintos e drasticamente reduzidos. Dois séculos de ocupação colonial implicaram a imposição de regimes de trabalho mercantis. E, em 1993, mediante um processo mobilizatório, conquistaram a demarcação, pelo Estado brasileiro, de um território para seu usufruto exclusivo. Atualmente ${ }^{8}$ esse grupo divide-se em comunidades, como denominam as aglomeraçóes de casas nas beiras dos rios maiores, como o Solimóes, e nas suas calhas. Nas comunidades maiores em extensão e número de habitantes havia igrejas de diferentes ordens religiosas, escolas públicas de ensino médio e fundamental, e um polo base da Secretaria Especial de Saúde Indígena (Sesai). ${ }^{?}$

Chefiavam, pela segunda gestão seguida, a Coordenação Técnica Local da Fundação Nacional do Índio (CTL-Funai); o Conselho Distrital de Saúde Indígena (CONDISI), órgão de representação indígena (das várias etnias do Alto Solimões) que compunha o Distrito Sanitário Especial Indígena (DSEI), braço local da Secretaria Especial de Saúde Indígena (SESAI); coordenavam as escolas instaladas em suas comunidades - cujos quadros de professores e funcionários era majoritariamente formado por indígenas - os polos de saúde locais, além de buscar incessantes diálogos junto ao poder local para reivindicar as melhorias destes serviços. Ocupar as posiçóes locais de controle destes órgãos, responsáveis pela gestão de seu território (incumbência da Funai), dos serviços de saúde oferecidos pela Sesai, assim como estimular a escolarização básica e superior eram assinaladas como estratégias cruciais e demandas obrigatórias, tanto em 
reuniôes e assembleias quanto em conversas informais. Por outro lado, as relaçôes rotineiras dos indígenas com estes serviços e, principalmente, com a centralização interna própria a estes órgãos ocorriam de modo impreterivelmente conflituoso, por conseguinte, os representantes e funcionários Ticuna estavam muitas vezes vulneráveis a destituição de suas posiçóes, cargos e funções, pelos próprios indígenas vinculados a outras redes de parentesco e/ou comunidades. Os Ticuna e sua mobilizaçáo política em prol da melhoria de suas condições de vida orbitavam e incluía os recursos do Estado, os mesmos que prejudicavam as relaçóes internas dos indígenas em virtude do princípio centralizador de gestão administrativa. Podemos, seguindo a interpretação de Ferreira (2014) sobre os Terena, nos reportar a esta dialética do político conformada pela dialética entre um sistema centralizador-hierárquico e um sistema emergente descentralizado-horizontal. Como o autor argumenta sobre as organizaçóes indígenas Terena e suas relaçôes com o Estado, estes sistemas apenas se realizam em um determinado contexto histórico de eventos, negociaçóes e conflitos, portanto não podem ser pressupostos como unidades apriori.

As principais atividades de sustento dos indígenas no Alto Solimões consistiam na agricultura e na pesca. Quanto a esta última, em geral todas as famílias dispunham de barco para pescar. Entretanto, com o avanço da pesca predatória no rio Solimões para a venda a frigoríficos dos municípios (cada vez mais populosos), a quantidade de peixes também diminuía a passos largos, sobretudo nas faixas do Solimões e açudes formados durante as cheias dos rios dentro das comunidades. No que diz respeito à agricultura, as áreas de cultivo na Amazônia se dividem em terras que inundam (de várzea ou igapó) nos períodos de cheia dos rios e terras que não inundam (terra firme).

Nem todas as famílias daquela comunidade dispunham de roças localizadas em várzea $e$ terra firme. As terras também estavam divididas conforme a antiguidade de chegada das famílias na comunidade, assim, a extensão das roças variava consideravelmente de família para família, de casa para casa. Logo, os alimentos que náo se produziam eram conseguidos mediante a troca ou compra, ali mesmo, com parentes e vizinhos, ou na feira de Polidoro Jordão. Além disso, o território demarcado em 1993 é frequentemente invadido pelo avanço da atividade madeireira. Em meio a este gradual confinamento, as fronteiras entre as roças eram frequentemente tema de conflitos entre indígenas, no mais das vezes vinculados por laços de parentesco.

Geralmente três geraçóes dividiam e trabalhavam no mesmo terreno, restringindo os cultivos a apenas alguns gêneros alimentícios. O que faltava tentavam comprar ou trocar em Manayunk ou em feiras próximas. Ter 
uma roça era um critério bastante valorizado, aos olhos dos sogros, para aceitar um candidato a genro ou nora. Caso um filho náo recebesse uma parte do terreno, poderia vir a ser professor, moto taxista ou trabalhar na área da saúde.

As crianças, meninas e meninos, eram estimulados a frequentar estes dois âmbitos distintos como forma de garantir futuramente seu sustento: acompanhar os pais à roça e na pesca e ir à escola. Se avançassem na formação escolar, poderiam se tornar professores ou trabalhar "na saúde". Concluindo o ensino fundamental e médio, cursos técnicos ou universitários, poderiam tornar-se professores primários e secundários, ou trabalhar nos polos de saúde como técnicos em enfermagem e agentes de saúde. Estas posiçôes laborais eram almejadas pois, considerando a sazonalidade incerta de recursos (alternância dos níveis do rio e quantidade de peixe) e os desdobramentos por vezes violentos das disputas com outros pescadores e extrativistas, ser professor ou agente de saúde lhes pareciam as estratégias mais seguras para sustentar a si e aos seus (crianças e velhos), embora restritos à quantidade de contrataçóes feitas pelo poder público, responsável pela gestão destes serviços.

A maioria dos meus interlocutores indígenas se viam ou viram às voltas com o dilema de qual atividade de sustento privilegiar, embora a principal recomendação dos mais velhos fosse aprender e dominar todas elas.

Era o caso de Ngematücü e Tutchianá, um jovem casal que conheci por meio de We'ena, irmã de Ngematücü. Os três residiam em Manayunk, comunidade à beira do rio Solimóes e muito próxima a Polidoro Jordão, que contava com uma estrutura urbana suficiente para receber a classificação de município: comércio, hospital, escolas, universidade, dentre outros órgáos públicos, mais assiduamente frequentados pelos indígenas que moravam próximos a este município. Quando os conheci, o casal tinha um filho de dois anos, e se deparavam com a eminência de separar-se. Ngematücü já pouco permanecia na comunidade de origem e trabalho de Tutchiãnã, para onde se mudou quando se casou. Os motivos da separaçáo eram o tema privilegiado de algumas conversas em que estive presente.

\section{"Traições" e yu u}

We'ena, seus pais, dentre outros parentes, por vezes conversavam sobre suas preocupaçóes com Ngematücü, de vinte anos, casado desde os quinze. ${ }^{10}$ Por alguns meses em que frequentava assiduamente nossa casa, ele transitava entre Topeka, onde sua esposa morava e trabalhava como agente de saúde, Manayunk, onde morava toda a sua família, e Polidoro Jordão, onde recém iniciara um curso universitário. Se dependesse dos parentes 
que viviam em Manayunk, sobretudo sua mãe e We' ena, ele pouco ou não mais voltaria a Topeka, com receio de que lá pudesse lhe acometer algo, onde não estariam perto para cuidá-lo. O risco decorria do comportamento sexual de sua esposa, Tutchianã, que se relacionava com outros homens, e "todos sabiam disso".

Ao mesmo tempo em que negava acusaçóes de que "traía" Ngematücü, Tutchianã não demonstrava nenhum ciúme quando presenciava flertes e elogios de seu marido dirigido a outras mulheres, tampouco insistia para que ele permanecesse em Topeka, o que contribuía para que seu comportamento fosse visto como uma demonstraçáo de indiferença em relação ao seu marido, ao mesmo tempo em que reforçava a veracidade dos comentários: "A gente pergunta para Tutchianã e ela nega que trai Ngematücü. Mas todo mundo sabe. Ela trai com o próprio cunhado, com o marido daquela irmá que tava aqui em casa no sábado dando de mamar para o filho", dizia We'ena, "ela tá muito feliz com Ngematücü longe [quando a perguntei sobre a permanência de seu irmão por tantos dias em Manayunk longe de sua esposa], é isso que ela quer, que ele se separe".

Tutchianã tinha a capacidade de matar Ngematücü por meio da feitiçaria, segundo We'ena

\begin{abstract}
"porque a pessoa é traída e não consegue se afastar, se separar, então é a outra pessoa que tá jogando feitiço. Por exemplo, A é casado com B. B trai A. Ao mesmo tempo, B vai jogar feitiço para A, pra A morrer logo e se livrar da pessoa”. (...) [Um tempo depois, retomando o assunto Ngematücü]: "Ele fala com ela, para ela parar, mas não adianta. Ela continua fazendo. Uma vez meus pais foram atrás dele em Topeka, para buscar ele, para ele não ficar lá com ela, e ele não quis vir. Eu acho que ela enfeitiçou ele, só pode. Porque ele não deixa ela...”.
\end{abstract}

Por "trair" meus interlocutores Ticuna se referiam ao ato de se relacionar com outras pessoas além da qual se coabita, independente da existência de filhos. Apropriando-se deste sentido, esta palavra em português era mencionada para se referir aos casos extraconjugais. Se esta importância atribuída às traiçóes é um reflexo da atuação cristâ, posto que todas as religiōes ali existentes propagam a conjugalidade monogâmica, é algo aquém das possibilidades deste trabalho conjecturar. Embora a frequência desta palavra nos diálogos possa sugerir uma necessidade coletiva em coibir a prática da poligamia, ocorriam muitas "traiçôes" em Manayunk, como constatava We'ena. Isto é, muitas mulheres se relacionavam com outros homens além 
dos quais coabitavam. Não por acaso, em sua explicação a parte traída é do sexo masculino e a parte traidora do sexo feminino. Enquanto homens que traem náo necessariamente eram enfeitiçados, porque a eles era dada certa prerrogativa de se relacionar com outras pessoas (mulheres e/ou homens) mesmo que porventura provocasse ciúmes, apenas ouvi histórias de mulheres que, traindo, enfeitiçavam.

Nisto baseava-se o receio demonstrado pelos pais de Ngematücü antes que ele se casasse com Tutchianã, a quem temiam por ser "mais velha", mais experiente. A obviedade de que o homem, a parte traída, está sob domínio de um feitiço, é porque ele não consegue se afastar da mulher que o trai. De acordo com sua explicação, ele está enfeitiçado porque, primeiro, está sendo traído, a na infidelidade feminina está implícita um antagonismo tão intenso que denota o desejo em "livrar-se" da pessoa. Segundo, porque não consegue se afastar da pessoa apesar de seus atos que demonstram que ela o repele.

Se os atos femininos são classificados na ordem da traição por oposição aos atos masculinos, isto não significa, porém, que havia um controle verticalizado de homens sobre mulheres, conforme os significados atribuídos ao comportamento sexual de Tutchianã evidenciam. Em suma, o comportamento sexual das mulheres se tornava uma preocupaçáo náo, em absoluto, em virtude de uma contaminação ou transgressão moral de seu corpo, mas somente em virtude do risco que passava a ser para a integridade física do homem a quem "traía". Segundo os comentários que ouvi, suas relaçóes com outros homens eram possibilidades absolutamente normativas. We'ena apontava os "outros namorados" de sua cunhada e outra conhecida em comum sem parecer atribuir à sua narrativa um julgamento de tais atos como transgressóes morais.

Em contrapartida, quando a conversa se ampliava para todas as pessoas implicadas neste "ato", o tom de voz se modificava para falar sobre os medos e proteçóes que deveriam cercar homens que eram traídos, proferidos com alarme e preocupação. O foco da preocupação recaía sobre o mal que poderiam causar já que traíam seus maridos, já que não os desejavam sexual e afetivamente. Quando as mulheres eram apontadas como pessoas que se relacionavam com mais de um homem, dirigia-se àquele reconhecidamente designado para controlá-la/satisfazê-la boa parte das preocupaçóes, pois assim ele tornava-se exposto como insuficiente, inábil em controlar/satisfazer a mulher com quem coabita e o "trai".

A vergonha suscitada pela traição recaía principalmente sobre a incapacidade masculina de satisfazer, de múltiplos modos, as necessidades e expectativas da mulher e da casa, de modo algum à poligamia feminina. Tampouco seu corpo estava disponível para servir de receptáculo dos ônus 
provocados pela ruptura da dignidade masculina. Aí residia a diferença entre a ofensa masculina e a ofensa feminina por ser traído. Um homem orgulhoso de suas habilidades e feitos deveria ser capaz de suprir as demandas e exigências da mulher e dos filhos, em termos de comportamento afetivo-sexual e de domínio das atividades necessárias à reprodução doméstica.

Tutchiânã era agente de saúde em Topeka, ocupação socialmente valorizada, que lhe assegurava certa independência doméstica em relação ao marido, além de torná-la mais cobiçada e sexualmente atraente. Ngematücü, por sua vez, embora dominasse com destreza algumas atividades primordiais para o sustento doméstico, como construir e manejar canoas, construir e fazer manutenção da casa, roçar e pescar, recém havia iniciado um curso universitário. Não era assalariado como Tutchiānã. A inserção dos indígenas em um universo mercadológico de prestígio constitui, assim, uma variável fundamental no exame sobre algumas crises referentes ao ideal masculino nesses contextos.

As relaçōes das mulheres com outras pessoas (homens e/ou mulheres) mostravam a um público que seus maridos falhavam em cumprir este ideal, tornando a vergonha contida na infidelidade imediatamente múltipla, ao partir de muitos lugares, olhares e vozes concomitantemente.

Isto não significa que mulheres não demonstrassem incômodos a respeito das outras relaçôes de seus maridos. Neste caso, uma ofensa semelhante apenas ocorria se houvesse o rompimento definitivo de sua relação conjugal. Homens provocavam ciúme nas mulheres quando as preteriam, não lhes tratavam bem ou ameaçavam romper definitivamente o vínculo com elas, deixando-lhes para coabitar com outra mulher. Para se perceberem as voltas com a iminente ameaça de terem que se despedir de seus maridos, as mulheres precisavam ouvir e saber dele próprio a vontade em deixá-las. Ou então ouvir de suas rivais a disposição em disputá-los para si. Do contrário, as relaçôes de seus maridos com outras mulheres pouco alterava a rotina de uma casa, por ser um ato relativamente aceito.

Homens se relacionando com outras mulheres não implicava necessariamente desprezar uma delas. Mulheres, conforme homens percebiam o alcance e dimensão dos desejos delas, sim. Tutchianá, ao trair, queria "se livrar" de Ngematücü. Sua indiferença alimentava o conhecimento por parte de Ngematücü e de pessoas próximas a ele, de "tudo o que Tutchianã fazia”, inclusive que enviava feitiços letais.

We'ena ainda afirmava com muita certeza que um dos homens com quem sua cunhada se relacionava era o marido da irmã de Tutchianã. Perguntei se ela sabia, e, em caso positivo, se reagia de alguma maneira. "Ninguém fica com raiva", respondia, "ela jogou feitiço para todos nós. A gente sabe de tudo o que ela faz, mas não consegue ficar com raiva dela". 
Certa vez pude ouvir de Ngematücü o que pensava sobre o assunto. Em uma conversa, ele perguntou-me se eu já tinha visto "alma" (correspondente a naë, no idioma Ticuna). Respondi que não, devolvendo-lhe a mesma pergunta. Entáo ele revelou que em Topeka, pouco tempo antes daquele dia, viu uma sombra andando atrás dele. Perguntei se a sombra lhe disse algo ou se ficara com medo. Apesar de náo ter visto nada, de tanto medo, saiu correndo. Tinha motivos suficientes para relacionar essas visóes aos comentários sobre a infidelidade de Tutchianá. Logo em seguida chegamos neste tema:

- Ela não ligaria se eu ficasse com outra pessoa - disse Ngematücü.

- Por que diz isso? - Perguntei.

- Porque sim, ela já falou. E eu acho que não ligaria mesmo. Você sabe o que ela faz, não é... Eu já sei, todo mundo sabe o que ela faz.

Sua mãe e We'ena se preocupavam, tentavam convencê-lo a voltar a morar em Manayunk, porque sabiam a proveniência dessas visóes. Temiam que acontecesse com Ngematücü o mesmo que ocorreu com o rapaz que trabalhava no pólo de saúde, quem já havia tentado suicídio $\left(m a{ }^{\prime} a\right)$ se asfixiando: "A gente tem muito medo, por isso a gente conversa com ele, mamáe tenta convencê-lo a ficar aqui, perto da gente, na casa dos meus pais. Mas ele tá enfeitiçado, não adianta. Ele acha isso e a gente também. A gente não quer fazer mal para Tutchianá, só quer que ela pare com isso. Porque se acontecer alguma coisa com ele, ela será a responsável”.

\section{Mulheres feiticeiras}

Quando "traía”, a mulher não estava transgredindo, em absoluto, uma expectativa coletiva quanto ao comportamento sexual feminino, mas seu ato dificultava as obrigaçóes e expectativas esperadas de um homem, fragilizando a dignidade dele. Homens viam mulheres como "metade humano, metade animal, a quem podem dominar, ordenar, dizer o que têm que fazer”, engravidando mulheres vezes o suficiente para que elas não olhassem e não se relacionassem com mais ninguém. Essa expectativa, entretanto, não era transposta automaticamente à mulher, ou seja, não era sua obrigação colaborar impreterivelmente com este ideal. As pessoas, não apenas o homem enfeitiçado, mas principalmente seus parentes mais próximos, nutriam temor pela mulher que "traía", e não menosprezo. Por conseguinte, as representaçóes ou preferências masculinas sobre os comportamentos sexuais femininos, não implicavam a obrigação de sua adoção por parte das mulheres. Homens desejavam a exclusividade de atenção das mulheres com as quais coabitavam, no entanto, essa preferência masculina não se convertia em imperativo moral sobre as mulheres. 
A especificidade dessas dinâmicas conjugais, tais como percebia na comunidade onde realizei minha etnografia, requer algumas informaçóes extras sobre o poder atribuído às mulheres Ticuna de enfeitiçar, algo pouco explorado ou refutado por etnografias sobre outras etnias indígenas. ${ }^{11}$

"Feiticeiros" reconhecidos por suas capacidades espirituais para curar e fazer o mal, fazendo desta habilidade quase um ofício, recebendo pessoas que solicitavam sua ajuda, eram majoritariamente homens. Durante meu trabalho de campo soube apenas da existência de uma "feiticeira", publicamente reconhecida enquanto tal, moradora de uma comunidade contígua a Manayunk. Quando convenci We'ena a procurá-la comigo, não a encontramos, tinha viajado por alguns meses - fugido de inimigos, conforme meias palavras sugeriram, “porque ela faz reza né...”. No entanto, por ocasião de uma infinidade de situaçôes, majoritariamente relacionadas a comportamentos classificados como invejosos, sovinas e ciumentos, mulheres, além de homens, explanavam a própria iniciativa em enfeitiçar alguém. Seja a propósito de uma disputa lúdica por um campeonato de futebol, ou uma vingança mais séria envolvendo a prisão de um parente próximo, mulheres diziam ter forjado feitiços para se vingar ou para se defender dos ataques enviados por alguém.

Com exceção da única feiticeira que soube da existência e com a qual nunca me encontrei, se perguntasse a cada uma dessas outras mulheres se eram, elas próprias, $y u^{\prime} u$ gare (feiticeiras), elas provavelmente diriam que não, ou a pergunta seria interpretada como uma ofensa - por esse motivo não me atrevi a fazê-la. Talvez argumentassem que, diferente dos homens feiticeiros, não possuíam conexão com dimensões espirituais, prerrogativa para ser considerado um feiticeiro com capacidade não apenas para fazer o mal, mas para curar também. Não obstante, elas também poderiam manipular objetos e substâncias, encantá-las, com o objetivo de neutralizar algum desafeto.

Poderíamos perguntar então por que escondiam deliberadamente esta habilidade, ou a frequência com a qual se valiam deste expediente em conflitos, ao não se assumirem publicamente como "feiticeiras". Invertendo a pergunta, qual seria o interesse em tornar públicas suas habilidades, como se pudessem e efetivamente praticassem malefícios regularmente, fazendo de si mesmas inimigas em potencial das pessoas com quem porventura entrassem em conflito? A eficácia da feitiçaria de vingança e/ou de proteção dispensava ameaças diretas. Os comentários e os comentários sobre os comentários eram suficientes para alimentar a suspeita de que se estava sob o ataque da feitiçaria. Ademais, auto intitular-se feiticeira(o) implicava atribuir para si uma rotina de ajudar pessoas e proteger-se de eventuais 
ataques - a exemplo da mulher que precisou viajar "[porque] fazia reza" mais do que o desenrolar dos conflitos cotidianos demandavam.

O importante a reter das múltiplas situaçóes que desencadeavam ameaças e sintomas atribuídos ao $y u^{\prime} u$, e a ampla e irrestrita participaçáo de qualquer pessoa nesta trama - mulheres e homens nos papéis de perpetradores ou vítimas - é que, independente do tema (roças, recursos, trabalhos, empréstimo de objetos), grande parte dos feitiços que ouvi decorriam de brigas relacionadas às essencialidades e trivialidades do cotidiano, entre pessoas e famílias próximas espacialmente, sendo os próprios envolvidos nos conflitos os autores do malefício (Ver WHITEHEAD e WRIGHT, 2004). Em menor frequência e gravidade, pessoas de comunidades distintas ou que pouco se encontravam também poderiam se tornar inimigos a ponto de acessar feiticeiros ou forjar feitiços sem ajuda especializada. Mas era a proximidade (territorial e de parentesco) e a vizinhança que proliferavam atritos e os medos do que poderiam fazer possíveis ou declarados desafetos. $Y u^{\prime} u$, portanto, restringe-se aqui às formas de decantar ou acentuar conflitos entre parentes, pessoas que se conheciam de longa data e compartilhavam espaços e intimidades. Mais do que uma forma ritualizada da disputa e concentração de poder, $y u$ ' $u$ é percebido aqui como formas de denunciar desafetos, de trazer à tona conflitos, de verbalizar suas dores e sintomas. O que faziam homens e também mulheres a todo o tempo.

Ampliando o escopo de análise para outras dimensóes do cotidiano, era possível tanto diferenciar quanto aproximar tarefas desempenhadas por mulheres e tarefas desempenhadas por homens. No que concerne ao problema da dualidade político e doméstico entre os Ticuna - ou, respectivamente, a apropriação da representaçáo da totalidade e da particularidade, como propóe Fausto (2001), não percebia qualquer separação rigorosa, linear e hierárquica nas duas principais atividades de sustento - a roça e a pesca, ambas executadas por homens e mulheres. Tampouco as outras tarefas cotidianas geralmente executadas por homens pareciam mais valorizadas do que as designadas a mulheres, quer no âmbito doméstico, quer no âmbito ritual.

Homens eram conhecidos por construírem canoas e caçar. Mulheres, por sua vez, aprendem a preparar fio de tucum e outros trançados para a manufatura de cestos e redes, e se dedicam aos bebês mais regularmente. Havia tarefas privilegiadamente executadas por mulheres, tarefas privilegiadamente executadas por homens, e as que ambos executavam juntos. No geral, homens e mulheres colaboravam juntos para o sustento da casa, o zelo com as crianças, velhos e eventuais outros agregados. Mulheres também se dedicavam aos bebês de colo enquanto dependessem do leite ma- 
terno. Após o desmame seguido do aprendizado de andar, o cuidado com as crianças era dividido entre mães, crianças maiores (geralmente do sexo feminino), e avós. Ainda muito pequenas, crianças acompanhavam seus pais até a roça. As mulheres também dividiam com homens, em número bastante similar e sem enfrentar grandes resistências masculinas, os cargos disponíveis nas áreas da "educação" e "saúde".

Se considerarmos espaços de construção decisória que afetavam diretamente o andamento coletivo das atividades locais, identifiquei três tipos na comunidade onde permaneci: a) fóruns hegemonicamente masculinos, em organizaçóes feitas por homens, por eles presididas. Nestes, a participação de mulheres era ativamente cerceada e, por conseguinte, irrisória; b) reunióes da comunidade, presididas por homens, mas abertas às intervençóes femininas, frequentes e sem enfrentar grandes censuras; c) por último, mulheres recentemente construíram suas próprias organizaçóes, nas quais era comum a interferência e participação de lideranças masculinas caso se tratasse de um projeto relevante para a coletividade mais ampla. Quando estava em jogo deliberar alguma questáo durante estes encontros e reunióes com atores vinculados de alguma maneira ao Estado, os homens presidiam o diálogo e demonstravam impaciência quando mulheres tentavam emitir suas opinióes. Com exceção do Conselho Geral, cujo propósito era reunir e mobilizar regularmente os caciques de cada uma das 183 comunidades Ticuna do lado brasileiro, contudo, as mulheres faziam-se presentes em número proporcional aos homens, como nas "reuniōes da comunidade", dentre outros fóruns com atores da administração pública dos municípios mais próximos, geralmente dedicados à questão da "saúde" e da "educação".

Baseando-me nestas observaçóes, sugiro que a hierarquia entre os sexos - se tomamos por "hierarquia" um esforço exitoso de determinado grupo para excluir/alienar um outro grupo - preponderava, curiosamente, nos espaços criados e mantidos a partir do diálogo com atores e instituiçóes "brancas": era o caso tanto das "associaçóes" e "organizaçóes" de múltiplas ordens descritas acima, quanto da Funai, Sesai, e das Igrejas. Se as mulheres participavam dos fóruns deliberativos, e suas opinióes, respeitada a diferença etária, eram ouvidas e respeitadas; se a diferença de participação correspondia à diferença dos próprios espaços, cujas valoraçóes por sua vez estavam subordinadas aos seus propósitos específicos da organizaçáo e à ausência ou presença de "brancos", "civilizados"12; se as organizaçóes masculinas mais cerradas, isto é, refratárias à participação das mulheres eram as fundadas em conjunto e diálogo com atores "brancos"; náo seria o caso de se perguntar se as análises que afirmam, direta ou sutilmente, uma hegemonia masculina nas posiçóes de "chefia" indígena na Amazônia não 
dizem mais sobre o tipo de relação tecida com os colonizadores, sobre o modus operandi e as orientaçôes míticas do Estado-nação (DAS, 2008), do que à restrição "natural" (sexualmente orientada) das mulheres ao dito "espaço doméstico" nestes grupos, ou sua alienação proposital das chamadas "funçōes políticas"?

Afora estes espaços construídos em diálogo com instituiçōes e atores 'brancos', as resoluçôes das atividades primordiais do cotidiano pareciam compartilhadas entre homens e mulheres. Isto náo significa que homens e mulheres eram vistos como "iguais".

Como procurei enfatizar há pouco, as demarcaçóes e tensóes de força entre os gêneros mais frequentemente assinaladas pelos meus interlocutores Ticuna não residiam em um inventário classificatório de funçóes, atividades e espaços, mas nos significados atribuídos aos comportamentos sexuais de homens e mulheres: na licença masculina em forçar o ato sexual - aspecto também notado por Franchetto (1996), sobre os Kuikuro, e McCallum (1999), sobre os Kaxinawá - e no frequente medo coletivo de mulheres promíscuas, classificadas como potenciais feiticeiras e assassinas de seus cônjuges - já que o significado para desejarem outros homens só poderia ser o desejo de "se livrarem" dos homens com os quais coabitavam e cujos comportamentos não as satisfaziam.

Este jogo ininterrupto entre forças, desejos e práticas irredutíveis uns aos outros, converge com as dinâmicas do $y u^{\prime} u$ (cuja tradução para a palavra "feitiçaria" merece ser objeto de problematizaçóes posteriores), forma por meio da qual os conflitos em geral são levados a cabo, caracterizada, não pela fixação identitária entre vítimas e algozes - que alimenta, por sua vez, a linguagem do sofrimento e a diluiçáo do conflito - mas pelo exercício difuso e ininterrupto da acusação. Localizo aí o problema da disponibilidade para a guerra indígena - ou um tipo particular de conquista e consumo da subjetividade de outrem - e da dissonância Ticuna se comparada às estratégias adotadas por outras etnias (CLASTRES, 2004; FAUSTO, 2001), mencionadas no início deste texto. Se as representaçóes sobre os Ticuna estáo corretas, de que a violência é direcionada, não para o plano coletivo da guerra contra outros coletivos, mas, sobretudo, contra afetos e desafetos consanguínea e residencialmente próximos (vizinhos e parentes), portanto mais perigosos, isto é, de que se morre muito mais de ofensas enfeitiçadas que circulam do que de violência física direta, isso abre possibilidades de reflexão sobre o estatuto dado aos regimes da violência dentre populaçóes indígenas, como propóe Vanzolini (2010, 2013).

Retornando ao argumento de Ferreira (2014), náo se trata de promover uma disjunçáo entre dois sistemas (estatal-centralizador e indígena-descen- 
tralizador) mas compreender como estes sistemas operam e se articulam a partir de movimentos e lutas históricas concretas. $\mathrm{O}$ autor atribui à luta pela terra a emergência de um sistema político horizontal, permeado por contradiçôes, mas assentado em condições específicas, sobretudo na 'retomada' enquanto forma de enfrentamento ao avanço da violência e expropriação territorial. A luta por terra e por direitos sociais desempenhou e desempenha igualmente um papel central na articulaçáo política dos ticuna e destes com outras etnias.

A instabilidade sexual permanente e a simultânea neutralização de forças típicas às relaçôes entre homens e mulheres Ticuna também estão atrelados à materialidade do sustento cotidiano. Isto implica que além de uma dinâmica de força específica entre homens e mulheres, um regime de violência que privilegia o conflito interno, é necessário também se considerar o conjunto de atividades de sustento cotidianas das quais os Ticuna se valem e estão inseridos (KERGOAT, 2010; LEA, 1999). Sugiro, portanto, que é nas tensóes e contradiçóes entre uma hierarquia nas suas organizaçôes indígenas - nas quais ecoam dinâmicas e performances centralizadoras - e uma equalização de forças nos âmbitos sexual e reprodutivo doméstico entre gêneros que a potencialidade para a horizontalidade e autonomia organizativa encontra uma firme âncora.

Algumas questóes levantadas ao longo deste texto mereceriam ser aprofundadas. Em que plano moral operam, ou quais definiçôes específicas são atribuídas a desejos e limites (ou as ideias de desejo e limite) nas dinâmicas afetivo-sexuais? Quais são as modalidades de violência normatizadas (a licença masculina em obrigar a mulher no ato sexual) e quais rompem até desencadear retaliaçóes (a insatisfaçáo e desprezo femininos diante dos comportamentos e insuficiências dos homens e o enfeitiçamento neles implícitos)? De que maneira estas modalidades afetivo-sexuais, representaçôes sobre o dever ser de comportamentos sexuais, e a trama do $y u^{\prime} u$ se tocam na conformação de um regime de violência específico? ${ }^{13}$

$\mathrm{O}$ estudo sobre as relaçóes entre homens e mulheres Ticuna pode permitir tanto a compreensão de um regime da violência marcado pela incompletude - aspecto que pode ser relacionado ao fato de que os Ticuna constituem a etnia indígena mais populosa do país - quanto a reflexáo sobre alguns corolários das imbricações entre gênero e violência, na medida em que o conjunto de práticas e mesmo de possibilidades de açáo imputadas a homens e mulheres por vezes escapava - escapar não necessariamente enquanto "desvio" ou "transgressão", mas como negaçáo esperada - às expectativas em relação ao gênero oposto, como procurei argumentar ao longo deste texto. 


\section{Notas}

1. As ideias centrais deste texto foram apresentadas no Seminário "Foucault na Amazônia? Sexualidades indígenas", organizados por Luisa Elvira Belaunde, Marina Vanzolini e Els Lagrou,a quem agradeço pela oportunidade do diálogo. Sou grata também a Laura Lowenkron e Caio Gonçalves Dias pelos comentários com os quais pude dar forma a uma versão preliminar deste texto; e à Caroline Bordalo, Joana Moroni e Rômulo Castro, pelas indicaçôes de leitura e pelo sempre valioso aprendizado.

2. Fabio Vaz de Almeida menciona dois termos para designar o "embate entre lideranças de diferentes grupos vicinais dentro da aldeia, o grupo vencido, ou seja, aquele que não conseguiu o que esperava, seja a indicaçáo de um parente para exercer cargos remunerados pelas prefeituras, estado ou mesmo pela Uniáo, seja ainda a construção de uma escola em um ponto determinado na aldeia, pode vir a manter uma situação de confronto com a liderança local até a um ponto onde a convivência se torna impossível. Acionando suas alianças neste embate, a situação freqüentemente chega a um ponto onde um dos dois grupos resolve se mudar, formando uma outra aldeia menor. Na língua ticuna é possível explicar todo esse processo com uma só palavra: ni'u. Quer dizer: "ele saiu brigado, foi morar em outro lugar”. É de se reparar que o fato é tão comum dentro daquela tradição cultural, que há uma palavra exclusiva para designá-lo. Há ainda uma outra palavra, derivada da primeira, que indica quando o Ticuna saiu da aldeia e foi morar em outro lugar por vontade própria. A palavra niu'gati parece indicar que o conflito é a regra, e que quando a decisão é pessoal, não estando relacionada a conflitos, o ticuna precisa explicar com a inclusão sufixo 'gati' " (ALMEIDA, texto não publicado).

3. Nas narrativas, feitiços eram associados à inveja e ao ciúme, ao desejo em ganhar pessoas e coisas presentes nas órbitas de outras pessoas.

4. As relaçôes entre homens e mulheres entre os ticuna não são feitas e influenciadas apenas por relaçóes heteronormativas, mas também pela relativa permissividade quanto às relaçóes entre pessoas do mesmo sexo, que às vezes se tornam coabitação, quando entre mulheres, ou permanecem como "amantes", quando entre homens.

5. Existem diferenças consideráveis entre as perspectivas destes autores, a despeito de trechos similares entre a teoria engeliana e bakuninista, como o uso de expressôes tais como "a família patriarcal - o embrião-protótipo do Estado teológico e sagrado (...), o forte sagrado de toda opressão (BAKUNIN, 2014 [1864], p. 92-93). Pois, como argumenta Ferreira (2014), a determinação conceituada pelos precursores da sociologia ou por uma teoria 
sociológica periférica, era relativa e não absoluta, como no caso da escola social-democrata alemã ou no caso da escola idealista francesa. A comparação entre essas perspectivas, seus desdobramentos para a teoria de gênero, e sobretudo dos efeitos dos apagamentos de interpretações histórico-filosóficas no âmbito sociológico para a consolidação de um olhar hegemônico e relativamente monolítico, é um trabalho ainda a ser explorado, considerando, ademais, que um vasto material da reflexão sobre experiências históricas revolucionárias, que formaram o pensamento sociológico, foi apenas recentemente compilado e traduzido para alguns idiomas a partir do ano 2000 - documentação reunida em um museu na Holanda, no International Institute of Social History.

6. Um movimento teórico recente tem sido incluir no estudo sobre as interseçôes também os afastamentos, isto é, depurar de que modo relaçôes sexuais e de força entre os gêneros transbordam os limites colocados pelo regime de agressôes e acusaçôes, e vice-versa, de que modo o regime da violência por vezes escapa às definiçóes prévias e às expectativas sobre o comportamento do gênero oposto (GREGORI, 1989, 2008, 2014).

7. Antes da chegada dos missionários, "os Ticuna eram índios de floresta tropical, moradores de terra firme e altos igarapés. Dominavam a técnica do curare, serviam-se da zarabatana e não possuíam canoas. Durante esse período anterior à chegada dos missionários, os Omágua dominavam a faixa ribeirinha e impunham sua supremacia militar aos Ticuna e demais povos da regiáo. $\mathrm{O}$ início da catequese dos Ticuna teria sido realizada entre 1683 e 1727, e gradualmente aglutinados em povoaçôes. Na última década do século XIX, comerciantes vindos do interior do Ceará estabeleceram-se na regiáo, apropriando-se dos terrenos ribeirinhos e promovendo nas matas, ao longo dos igarapés, a abertura de grandes seringais nativos. A mão de obra fundamental para isso foi indígena, desde o início. A expropriação fundiária e o controle do trabalho indígena foram processos realizados de maneira simultânea por meio de um ato básico de força - a destruição das malocas - e pela administração posterior de seus desdobramentos. No decorrer do primeiro quartel do século $\mathrm{XX}$, as malocas das diferentes 'naçôes' foram derrubadas e os índios, distribuídos em famílias nucleares nas 'colocaçôes' dos seringais. A imposição das mercadorias (e em especial da cachaça), o endividamento ao barracão e o surgimento dos 'tuxauas' como prepostos dos patróes foram os instrumentos usados para estabelecer a sujeição dos índios. Atravessaram, neste sentido, um longo caminho de interlocução, guerras e disputas territoriais com diferentes grupos, sobretudo contra os Omágua (ou Cambeba) e contra os "brancos" - aí incluídos não apenas os patrôes seringalistas, mas toda sorte de instituiçôes, atores sociais e atividades que enredaram os indígenas após a ocupação colonial” (OLIVEIRA, 2000, p. 280-282). 
8. Esta pesquisa foi realizada ao longo dos anos de 2011 e 2012.

9. A Secretaria Especial de Saúde Indígena (Sesai) é vinculada ao Ministério da Saúde (Governo Federal) responsável por coordenar a Política Nacional de Atenção à Saúde dos Povos Indígenas e todo o processo de gestão do Subsistema de Atenção à Saúde Indígena (SasiSUS), no âmbito do Sistema Único de Saúde (SUS). Fonte: <http://portalsaude.saude.gov.br/index. php/conheca-a-secretaria-sesai>. Acesso em 20/02/2016.

10. Atribuí nomes fictícios aos meus interlocutores e aos lugares.

11. Com Nimuendajú, etnólogo a se ater especificamente sobre este aspecto, inaugura-se uma lacuna semelhante sobre os Ticuna Embora se reporte a todos os feiticeiros utilizando artigos e pronomes masculinos, é interessante notar que a origem do xamanismo foi narrada a Niumendajú por meio das habilidades aprendidas e repassadas por Auë'mana, uma mulher (NIMUENDAJÚ, 1952:100): “Quando Auë'mana tinha dois anos de idade, ela costumava chorar muito durante a noite. Sua mãe ficava nervosa e a colocava para dormir fora de casa, fechando a porta. Auë'mana chorava sozinha no quintal durante a noite inteira até que um sapo viesse e ele a levasse consigo. Ela permaneceu em sua companhia até crescer, aprendendo com ele todas as artes mágicas, desde matar até curar por sucçấo. Mais tarde ela retornou para viver entre humanos para praticar magia. Muitos aprenderam a arte, desde então a magia se tornou conhecida. Auë'mana, já envelhecida e desprovida de força física, pediu algumas meninas para preparar-lhe comida. Elas recusaram o pedido porque não gostavam dela. Entáo durante a noite, enquanto dormiam, Auë'mana extraiu os ossos de suas pernas. Na manhã seguinte elas a viram sentada atrás do fogo comendo seus ossos, única fonte de alimento que tinha. As meninas não podiam levantar-se. Quando isso foi amplamente divulgado, as pessoas mataram Auë'mana, cortando seu pescoço com uma faca de pedra. Ela pegou o sangue que escorria, em sua mão em forma de concha, soprou em direção ao sol, e disse: "A alma entra em ti, eu também". Desde então, a alma de uma vítima entra no corpo do assassino". [Tradução minha]

12. As categorias "branco" e "civilizado" referem-se a pessoas não-indígenas, descoladas daquele universo em termos de linguagem, ocupação e comportamento, independente se possuíssem características fenotípicas de descendência indígena, o que era frequente.

13. Poucos avanços foram feitos, como aponta McCallum (2013), no sentido de investigar o domínio da sexualidade entre povos indígenas, não obstante a centralidade do gênero como categoria de diferenciação social entre estas populações. A autora sugere ainda que uma "discussão bibliográfica comparativa do que essa literatura etnológica diz sobre gênero e sexualidade 
seria o primeiro passo para aprofundar nosso entendimento nessa área (o mesmo poderia ser dito sobre o amor hetero e homossexual entre os povos indígenas) ”.

\section{Referências bibliográficas}

ALMEIDA, Fabio Vaz de. Tatchiüãne: "Nossa terra de muito tempo" (Texto não publicado).

BAKUNIN, Mikhail. Consideraçóes filosóficas sobre o fantasma divino, o mundo real e o homem. In: FERREIRA, A. C.; TONIATTI, T. (Orgs.) De baixo para cima e da periferia para o centro: textos políticos, filosóficos e de teoria sociológica de Mikhail Bakunin. Editora Alternativa, Niterói, 2014.

CLASTRES, Pierre. Arqueologia da violência. In: Arqueologia da violência: pesquisas de antropologia política. São Paulo: Cosac \& Naify, 2004 [1977].

DAS, Veena. Suffering, Legitimacy and Healing: the Bhopal Case. In: DAS, Veena. Critical Events: An Anthropological Perspective on Contemporary India. Oxford Univ. Press, Delhi, 1995.

. Violence, Gender and Subjectivity. In: Annual Anthropological Review, 2008; 37:283-299.

ENGELS, Friederich. A origem da família, propriedade e Estado. Ed. Civilização Brasileira, 1975.

FAUSTO, Carlos. Inimigos Fiéis: história, guerra e xamanismo na Amazônia. Edusp, São Paulo, 2001.

FEDERICI, Silvia. Calibán y la bruja: mujeres, cuerpo y acumulación originaria. Ed. Traficantes de Sueños, Madrid, 2010.

FERREIRA, Andrey C. e TONIATTI, Tadeu Bernardes de Souza. Apresentação - o estado dos estudos e das publicações sobre anarquismo no Brasil hoje. In: De baixo para cima e da periferia para o centro: textos políticos, filosóficos e de teoria sociológica de Mikhail Bakunin”. Editora Alternativa, Niterói, 2014.

FERREIRA, Andrey C. "Anarquismo, pensamento e práticas insurgentes: fenômeno da "Primeira Internacional"? In: FERREIRA, A. C.; TONIATTI, T. (Orgs.) De baixo para cima e da periferia para o centro: textos políticos, filosóficos e de teoria sociológica de Mikhail Bakunin”. Editora Alternativa, Niterói, 2014.

Mudança social, coletivismo e povos indígenas: a luta pela terra como fator de transformaçáo do sistema político. Paper apresentado ao Congresso da ALASRU, 2014.

FRANCHETTO, Bruna. Mulheres entre os Kuikúro. In: Revista Estudos Feministas, v. 4, n.1, pp. 35-54, 1996. 
GREGORI, Maria Filomena. Cenas e queixas: mulheres e relaçôes violentas. In: CEBRAP, 1989. No 23 (pp. 163-175). . As desventuras do vitimismo. In: Estudos feministas v. 143, no 1, 1993. . Limites da sexualidade: violência, gênero e erotismo. In: Revista de Antropologia (USP), v. 51 no 2. São Paulo, 2008.

. Práticas eróticas e limites da sexualidade: contribuiçôes de estudos recentes. In: Cadernos Pagu, (42), janeiro-junho de 2014:47-74, 2014.

GREGORI, Maria Filomena; DEBERT, Guita Grin. Violência e gênero: novas propostas, velhos dilemas. In: Revista Brasileira de Ciências Sociais, Vol. 23 nº. 66, Fevereiro/2008.

KERGOAT, Danièle. Dinâmica e consubstancialidade nas relaçóes sociais. In: Novos Estudos CEBRAP. 86, pp. 93-103, 2010.

LEA, Vanessa. Desnaturalizando Gênero na Sociedade Mebengôkre. In: Revista Estudos Feministas, v.7, n. 1 e 2, pp. 176-194, 1999.

MAGALHÁES, Aline Moreira. Esquecer-se de si: morte, emoçóes e autoridades em uma comunidade Ticuna. Tese de doutorado - PPGAS-UFRJ, 2014.

McCALlUM, Cecilia. Aquisição de Gênero e Habilidades Produtivas: o caso Kaxinawá. In: Estudos Feministas, v.7, n. 1 e 2, p.157-175, 1999.

. Notas sobre gênero e sexualidade entre povos indígenas. In: Cadernos pagu (41), julho-dezembro de 2013:53-61.

MORGAN, Lewis Henry. A sociedade primitiva. Lisboa: Presença, 1973 [1877]. . Systems of consanguinity and affinity of the human family. Oosterhout: Anthropological Publications, 1970 [1871].

OLIVEIRA, João Pacheco de. "O Nosso Governo": Os Ticuna e o regime tutelar. Ed. Marco Zero, São Paulo, 1988.

Sobre macacos, índios e peixes: narrativas e memórias da intolerância na Amazônia contemporânea. In: Etnográfica, Vol. IV (2), pp. 285-310, 2000.

SOARES, Marília Facó. Ordem de palavra: primeiros passos para uma relação entre som, forma e estrutura em Ticuna. In: Amerindia: A.E.A: Paris, 1992.

STRATHERN, Marilyn. O Gênero da Dádiva: problemas com as mulheres e problemas com a sociedade melanésia. Ed. Unicamp, 2008.

VANZOLINI, Marina. A flecha do ciúme: O parentesco e seu avesso segundo os Aweti do Alto Xingu. Tese de doutorado (PPGAS-UFRJ), 2010.

. Ser e não ser gente: dinâmicas da feitiçaria no Alto Xingu. In: $M A N A$ 19(2): 341-370, 2013.

WHITEHEAD, Neil \& WRIGHT, Robin. Introduction. In: In darkness and secrecy: The anthropology of assault sorcery and dark shamanism in Amazonia. Durham \& London: Duke University Press. 
486 | Aline Moreira Magalhães

WRIGHT, Robin. 2004. The wicked and the wise men: witches and prophets in the history of the Northwest Amazon. In: WHITEHEAD, N. L.; WRIGHT, R. (eds.). In darkness and secrecy. The anthropology of assault sorcery and dark shamanism in Amazonia. Durham \& London: Duke University Press. pp. $82-108$

Recebido em 10/12/2015

Aceito para publicaçáo em 10/12/2015 